\title{
Reviewing the Concept of Brand Equity and Evaluating Consumer- Based Brand Equity (CBBE) Models
}

\author{
Sanaz Farjam ${ }^{1}$, Xu Hongyi ${ }^{2}$ \\ School of Management, Wuhan University of Technology, Wuhan, P.R.China, 430070 \\ Email: farjam8@ymail.com
}

\begin{abstract}
The purpose of this paper is to explore the concept of brand equity and discuss its different perspectives, we try to review existing literature of brand equity and evaluate various Customer-based brand equity models to provide a collection from well-known databases for further research in this area.
\end{abstract}

Keywords: Brand equity models, Brand equity dimensions, Consumer-based brand equity, Cross-national brand equity

\section{Introduction}

An attempt to define the relationship between customers and brands produced the term "brand equity" in the marketing literature (Wood, 2000). The brand equity generates a type of added value for products which help with companies' long term interests and capabilities (Chen, 2008). Over the past two decades, a great deal of research has addressed various aspects of brand equity; brand equity is generally accepted as a critical success factor to differentiate companies and service providers from its competitors. Brands with high levels of equity are associated with outstanding performance including sustained price premiums, inelastic price sensitivity, high market shares, and successful expansion into new businesses, competitive cost structures and high profitability all contributing to companies' competitive advantage (Keller and Lehmann 2003; Vazquez et al. 2002 ).

Brand equity is significant in assisting consumers to process information, especially, when the information is overloaded (Krishan and Hartline, 2001). For firms, growing brand equity is a key objective to be achieved by gaining more favourable associations and feelings of target consumers (Falkenberg 1996). In other words, financial meaning from the perspective of the value of the brand to the firm and customer-based meaning from the perspective of the value of the brand to the customer which both come from a marketing decision-making context (Kim, and An 2003). In addition, Yoo, at el (2000) states that understanding the dimensions of brand equity and investing to its growth raises competitive barriers and drives brand wealth. The subject of brand equity is very rich in the context of definitions, models and measurement issue; several brand equity measurement methods have been suggested by different researches. Considering the importance of this topic, our paper aims at improving and reinforcing the current knowledge of brand equity. More specifically, the study pursues three objectives:t o discuss different perspectives of brand equity; to provide a collection of Customer-based brand equity measurement models; to revise the application of brand equity in different sectors.

\section{The concept of brand equity}


During the past few decades, brand equity has become one of the major areas of attention to managers and marketing researchers owing to its major role as a significant intangible firm asset. Many definitions of brand equity exist (table 1). One of the most widely accepted definitions states that brand equity is the "added value endowed by the brand to the product" (Farquhar 1989). There are some other definitions by other researchers as well. Aaker (1991) conceptualized brand equity as a set of brand assets and liabilities linked to a brand, its name and symbol that add to or subtract from the value provided by a product or service to a firm and/or to that firm's customers. Definition by Keller (1993) focused on marketing; he described brand equity as "the differential effect of brand knowledge on consumer response to the marketing of the brand". Brand equity has also been defined as "the enhancement in the perceived utility and Desirability a brand name confers on a product" (Lassar, Mittal and Sharma 1995). Vázquez et al. (2002) mentioned that brand equity is the utility that the consumer associates to the use and consumption of the brand. Clow and Baack (2005) pointed out another definition: they considered brand equity as a set of characteristics that make a brand unique in the marketplace, allows the company to charge a higher price and retain a greater market share than would be possible with an unbranded product.

We can evaluate the brand equity from different perspectives, As Baalbaki (2012) mentioned brand equity can be seen from three different perspectives, in next part of article we are going to discuss each of them, (see figure 1).

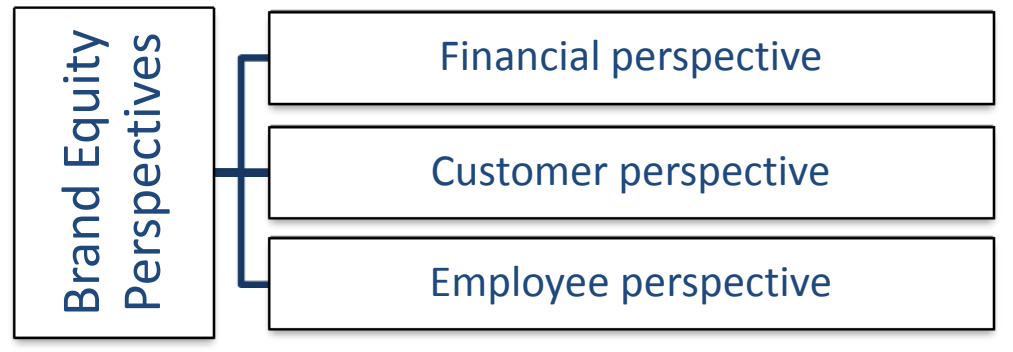

Figure 1. Brand Equity Perspectives

\subsection{Financial perspective (Financial- based brand equity)}

Brand equity in the 1980s, as seen from the financial perspective, was viewed as a method that gave managers guidance in understanding brand enhancement. In this perspective, the measures focused on stock prices or brand replacement (Myers, 2003). Simon and Sullivan (1993) defined brand equity as "the incremental cash flows which accrue to branded products over and above the cash flows which would result from the sale of unbranded products". Supporters of the financial perspective (FBBE) define brand equity as the "total value of a brand which is a separable asset - when it is sold or included in a balance sheet" (Atilgan et al., 2005). Wood (2000) discussed that from a financial perspective it is possible to give a monetary value to the brand that can be useful for managers in case of merger, acquisition or divestiture. Estimating a financial value for the brand is certainly useful but it does not help marketers to understand the process of building brand equity. Wood (2000) believes that marketing perspective of brand equity can help marketers to understand the brand in the minds of customers and to design effective marketing programs to build the brand.

\subsection{Customer perspective (Customer-based brand equity)}

Extant literature on brand equity has focused on the perspective of cognitive psychology (Christodoulides and de Chernatony, 2010) known as consumer-based brand equity. The customer-based brand equity (CBBE) approach is the dominant perspective and the one preferred by a majority of academics and practitioners in marketing research because if a brand has no meaning or value to the consumer it is ultimately meaningless to investors, manufacturers, or retailers (Cobb-Walgren et al., 1995). Motameni (1998) also mentioned this perspective as a marketing perspective. He used the concept of brand equity in the context of marketing decision-making. Keller (1993) used the term consumer-based brand equity to refer to brand equity and noted that customer-based brand equity occurs when the consumer is familiar with the brand and holds some favourable, strong and unique brand associations in their memory. Positive customerbased brand equity has many advantages like long term revenues, customers' willingness to seek out for themselves new channels of distribution, the ability of firms to command higher prices and the effectiveness of marketing communications (Keller, 2003). Several scholars (e.g. Cobb-Walgren et al, 1995; Yoo and Donthu, 2001) have 
theorized brand equity similar to Aaker (1991). Although Aaker (1991) and Keller (1993) conceptualized brand equity in a different way, both defined brand equity from customer perspective. Szőcs (2012) mentioned that Consumer-based brand equity is referred in literature as a decision support tool that sets up a useful diagnosis for the managers about the ideas consumers have about the brand. Consumer-based brand equity can be best formulated as a construct caused by brand-related associations in which the effect of brand-related associations is concentrated. In order to be able to make recommendations to managers on how to manage their brand equity or study the nomological network of its constituent components, we need to generate a better understanding of the composition of brand equity in disparate cultural contexts and distinct product categories (Christodoulides at el, 2015).

\subsection{Employee perspective (Employee-based brand equity)}

Youngbum Kwon (2013) discussed that the definitions of Employee-based brand equity and Customer-based brand equity are similar in respect that they are both values that come from the innate nature of the brand. Employee-based brand equity is defined from the employee perspective and is based on the differential effect that brand knowledge has on an employee's response to his or her work environments and cultures (King and Grace, 2009). Youngbum Kwon (2013) presented a three dimension model based on King and Grace (2009, 2010) and Aaker (1991) research.

Table 1. Definitions of brand equity

\begin{tabular}{|c|c|}
\hline Researcher & Definition \\
\hline Farquhar( 1989) & Added value endowed by the brand to the product \\
\hline Aaker (1991) & $\begin{array}{l}\text { Set of brand assets and liabilities linked to a brand, its name and symbol that } \\
\text { add to or subtract from the value provided by a product or service to a firm } \\
\text { and/or to that firm's customers. }\end{array}$ \\
\hline Keller (1993) & $\begin{array}{l}\text { The differential effect of brand knowledge on consumer response to the } \\
\text { marketing of the brand }\end{array}$ \\
\hline $\begin{array}{l}\text { Simon and Sullivan } \\
\text { (1993) }\end{array}$ & $\begin{array}{l}\text { Cash flow differences between a scenario where the brand name is added to a } \\
\text { company product and another scenario where the same product does not have } \\
\text { brand name. }\end{array}$ \\
\hline $\begin{array}{l}\text { Rangaswamy et al., } \\
\text { ( 1993) }\end{array}$ & Favorable impressions, attitudinal dispositions, and behavioral predilections \\
\hline $\begin{array}{l}\text { Lassar, Mittal and } \\
\text { Sharma (1995) }\end{array}$ & $\begin{array}{l}\text { The enhancement in the perceived utility and Desirability a brand name } \\
\text { confers on a product }\end{array}$ \\
\hline $\begin{array}{l}\text { Park and Srinivasan } \\
\text { (1994) }\end{array}$ & $\begin{array}{l}\text { The difference between overall brand preference and multi attributed } \\
\text { preference based on objectively measured attribute levels }\end{array}$ \\
\hline Yoo et al., (2000) & $\begin{array}{l}\text { The difference in consumer choice between a branded and unbranded } \\
\text { product, given the same level of features }\end{array}$ \\
\hline Vázquez et al., (2002) & $\begin{array}{l}\text { The utility that the consumer associates to the use and consumption of the } \\
\text { brand. }\end{array}$ \\
\hline Ailawadi et al., (2003) & $\begin{array}{l}\text { Outcomes that accrue to a product with its brand name compared with those } \\
\text { that would accrue if the same product did not have the brand name" }\end{array}$ \\
\hline Baldauf et al., (2003) & $\begin{array}{l}\text { Reflection of the premium price the firm charges for a strong brand } \\
\text { combined with the sales it is able to attract compared to other average brands } \\
\text { in the same product category }\end{array}$ \\
\hline Clow and Baack (2005) & Set of characteristics that make a brand unique in the marketplace \\
\hline $\begin{array}{l}\text { Kotler and Keller } \\
\text { (2006) }\end{array}$ & $\begin{array}{l}\text { A bridge between the marketing investments in the company's products to } \\
\text { create the brands and the customers' brand knowledge }\end{array}$ \\
\hline Yasin et al., (2007) & $\begin{array}{l}\text { Consumers' favoritism towards the focal brand in terms of their preference, } \\
\text { purchase intention and choice among brands in a product category, that offers } \\
\text { the same level of product benefits as perceived by the consumers. }\end{array}$ \\
\hline
\end{tabular}

The three dimensions are Brand knowledge, Role Clarity, Brand commitment. Cardy et al (2007) argued that subjective and emotional employee judgments concerning an organization reflect brand equity in the reflection of several following questions: what is the employee perception of an organization's reputation; does it convey a sense of respect to its members; does an individual associate certain emotions, lifestyles, or experiences with an organization; has an 
employee forged an organizational identity, or considered the firm a part of himself or herself (Ashforth and Mael, 1989). All these questions describe subjective, intangible factors that imply developing an emotional tie with a firm or its culture. In a marketing sense, brand equity results in increasing the positive feelings that make one less likely to defect to a competing product. HRM can adopt the brand equity concept to strengthen the psychological contract with employees and make them less likely to leave. According to King and Grace (2009), Employee-based brand equity serves as a foundation to build Customer-based brand equity because employees who understand and wholeheartedly endorse the organization's objectives deliver these values to their customers. In fact, employees are important resources for company brand success (de Chernatony 1999; de Chernatony et al. 2003).

\section{Measuring customer-based brand equity}

De Chernatony and Cottam (2006) suggest that rather than one comprehensive methodology to evaluate brand success, there are a range of financial and non-financial measures that collectively provide the necessary insight. Agarwal et al (1996) explained that there are two different approaches to measure brand equity; direct approach and indirect approach. The direct approach tries to assess the added value of the brand and appears to be the accepted definition of brand equity (Farquhar, 1989; Keller, 1993). The indirect approach tries to identify the potential sources of brand equality. An understanding of these sources for a firm's own and competitive brands is critical for the brand manager (Keller, 1993). Agarwal et al (1996) argued that both these authors (Aaker and Keller) suggest a variety of indirect measures and methods to estimate brand equity based on their frameworks.

For example, Aaker (1991) suggests using repurchase rates, switching costs, level of satisfaction, preference for brand and perceived quality on various product and service dimensions as potential measures among others. Likewise, Keller (1993) suggests correct top-of-mind recall, free associations, ratings of evaluations, and beliefs of associations as some of the measures of brand knowledge. Ravi (2005) argued that developing further insights into the measurement of consumer based brand equity is important in the face of the prominence of branding. Understanding the dimensions of brand equity, then investing to grow this intangible asset raises competitive barriers and drives brand wealth (Yoo, Donthu and Lee 2000). How to measure brand equity is very important in assessing the value of brands. Further, we are going to discuss different models of CBBE.

\subsection{Aaker's brand equity model}

Aaker (1992) provided the most comprehensive brand equity model which consists of five different assets that are the source of the value creation. These assets include: brand loyalty; brand name awareness; perceived brand quality; brand associations in addition to perceived quality; and other proprietary brand assets - e.g., patents, trademarks, and channel relationships.

\subsubsection{Brand loyalty}

Based on Aaker's model, Ovidiu (2005) discussed that Brand loyalty generates value by reducing marketing costs and leveraging trade. Loyal customers expect the brand to be always available and entice others advising them to use it. Retaining existing customers is much less costly than attracting new ones. Even if there are low switching costs, there is a significant inertia among customers. It is also difficult for competitors to communicate to satisfied brand users because they have little motivation to learn about alternatives. Therefore, competitors may be discouraged from spending resources to attract satisfied and loyal customers and even if they do so, this requires a long time. Aaker (1992) believes that focusing on brand loyalty is often an effective way to manage equity. Also, Pitta and Katsanis (1995) suggested that brand equity increases the probability of brand choice, leads to brand loyalty. 


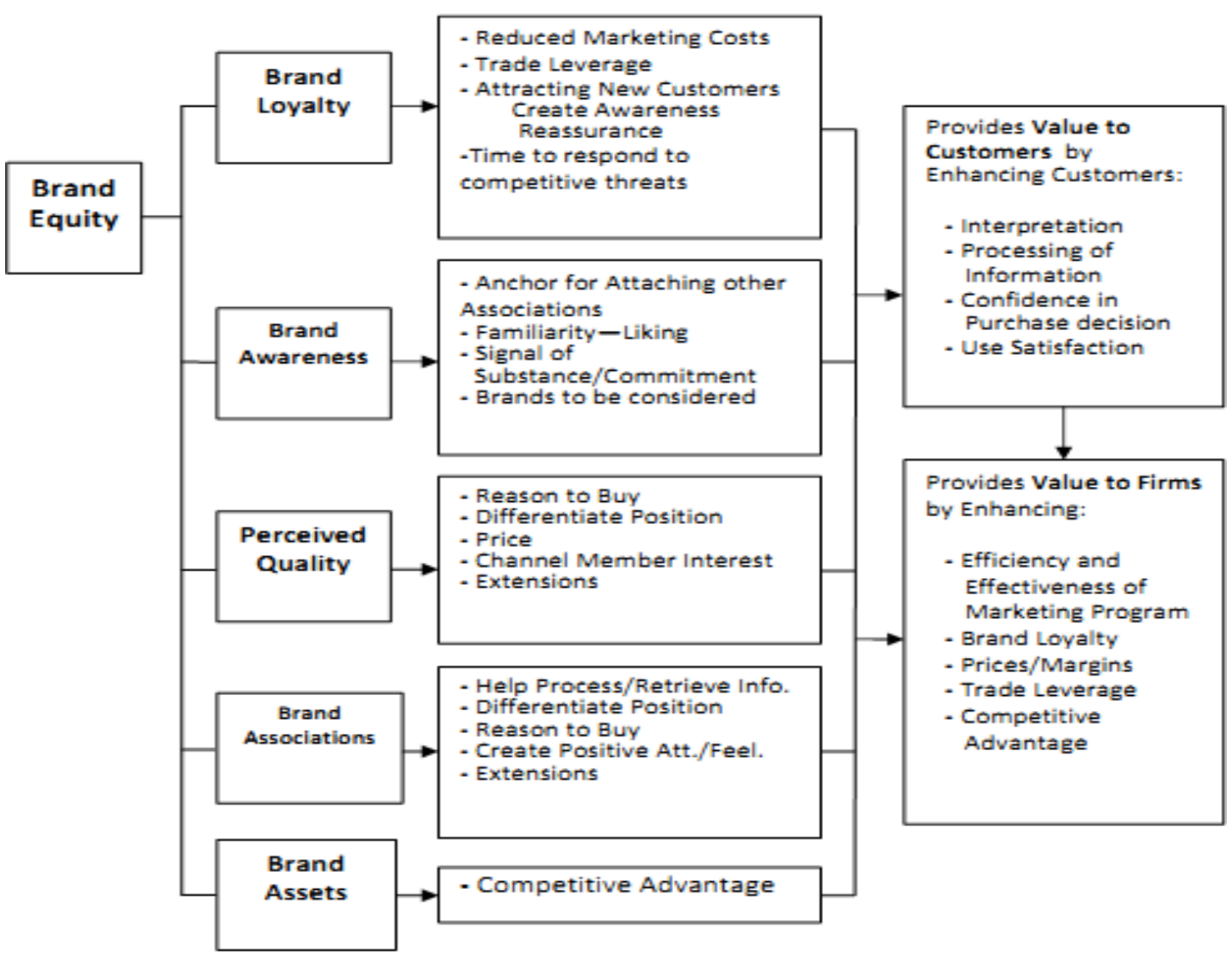

Figure 2. Aaker's Customer-Based Brand Equity Framework (source: Aaker's $(1992,1996))$

\subsubsection{Brand name awareness}

Brand awareness is a key and essential element of brand equity which is often overlooked (Aaker, 1996). Brand awareness refers to "the ability of a potential buyer to recognize or recall that a brand is a member of a certain product category" (Aaker, 1991). Brand awareness has different level; at the recognition level, it can provide the brand with a sense of the familiarity as well as a signal of substance, commitment and awareness and at the recall level, it further affects choice by influencing what brands get considered and selected. For many companies, brand awareness is pivotal and it underlies the strength of successful brands (Aaker, 1992). Awareness plays an important role in most of conceptual models of brand equity. Brand awareness generates a high level of purchase, mainly because consumers are likely to buy those brands they are familiar with enhancing the firm's profitability and sales (Baldauf et al., 2003).

\subsubsection{Perceived brand quality}

Aaker (1992) explained that perceived quality provides value by providing a reason to buy, differentiating the brand, attracting channel member interest, being the basis for line extensions, and supporting a higher price. In other words, perceived quality is the consumer's judgment about a product's overall excellence or superiority (Zeithaml, 1988). Perceived quality is included as an asset distinct from brand. It has become an important business thrust for many firms and can be the motivation for programs designed to enhance brand equity. Perceived quality is a sufficiently important and accepted strategic consideration (Aaker, 1992).

\subsubsection{Brand associations}

Brand associations or brand image is perhaps the most accepted aspect of brand equity. In fact, it is anything linked in customers' memory to a brand. Brand association include product attributes, customer benefits, uses, users, life-styles, product classes, competitors and countries. Associations can help customers process or retrieve information, be the basis for differentiation and extensions, provide a reason to buy, and create positive feelings. Consumers use brand associations to process, organize, and retrieve information in memory and this helps them to make purchase decisions (Aaker, 1991. 1992). In order to build strong brand equity in the market, it is fundamental to understand the core 
dimensions of brand image, which is brand personality (Lee at el, 2006). When there is a higher level of brand association, there is a higher tendency for brand extension to become relevant to customers.

\subsubsection{Brand assets}

Based on Aaker's model, Ovidiu (2005)discussed that brand assets refers to patents, trademarks and channel relationships which can provide strong competitive advantage. Trademark protects brand equity from competitors who might want to confuse customers by using a similar name, symbol or package. Patent can prevent direct competition if strong and relevant to the purchase decision process. Finally, a distribution channel can be indirectly controlled by a brand as customers expect the brand to be available.

\subsection{Keller's brand equity pyramid}

Keller (1993) defined consumer-based brand equity at individual level taking brand knowledge as a starting point, which is conceptualized as an associative network, where the associations are nodes. In 2003, he defined brand equity as differences in customer response to marketing activity. The concept behind the brand equity is to form how customers think and feel about the product or service relying on positive experience. A company should create a situation that your customer will have positive thoughts and feelings and perceptions concerning the brand. Keller model identifies 6 elements including brand salience, brand performances, brand imagery, brand feelings, brand judgments and brand relationships.
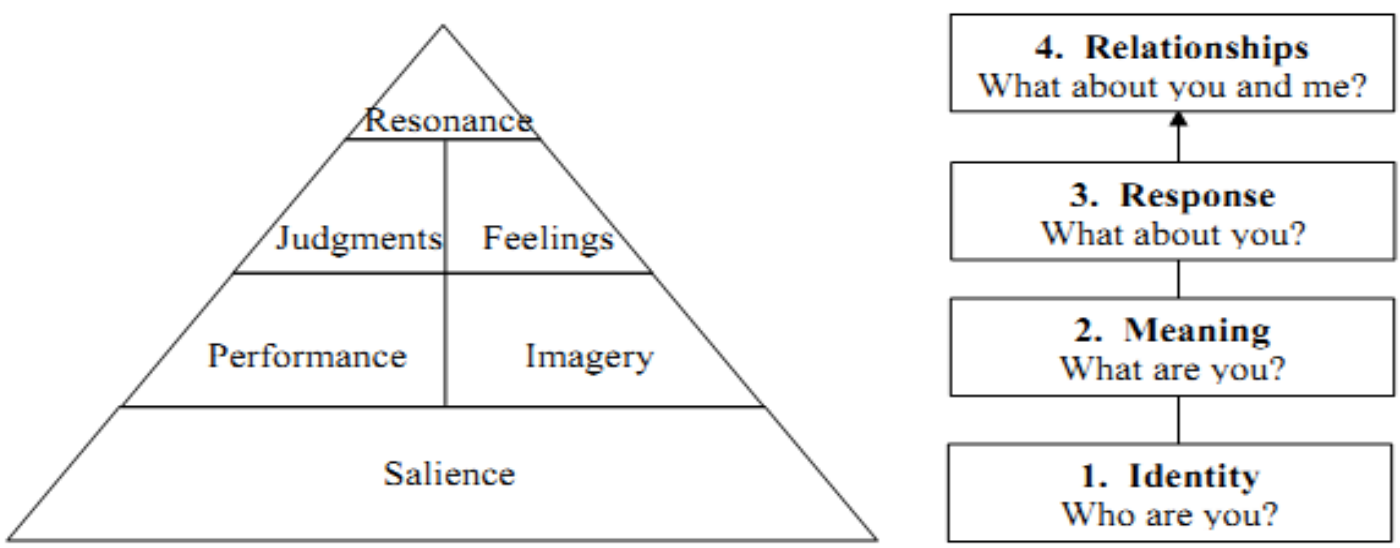

Figure 3. Keller's Customer-based Brand Equity Pyramid

The first stage relates to brand identity and uses brand salience as a measure of the awareness of the brand (Keller, 2008). Formally, brand awareness refers to customer's ability to recall and recognize the brand; brand awareness also involves linking the brand name, logo and symbol to certain association in memory. Building brand awareness involves making sure that customer understand the product or service category in which the brand competes (Keller 2001). Based on Keller's model, Kerri-Ann et al (2008) explained that the first step in building a strong brand is to ensure the correct brand identity; the purpose is to create an identification of the brand with customers and an association in their minds with a specific product class or need. To do this, brand salience must exist, which represents aspects of brand awareness and the range of purchase and consumption situations in which the brand comes to mind. The salience building block is, therefore, made up of two sub-dimensions - need satisfaction and category identification.

Kerri-Ann et al (2008) discussed the second step of Keller's model as establishing brand meaning by linking tangible and intangible brand associations. Brand meaning is, therefore, characterised in either functional (brand performance) or abstract (image-related) associations. Brand response is the third step in the Keller's model and represents opinions and evaluations of the brand based on a combination of associations identified in brand meaning. These judgments include overall quality, credibility, consideration and superiority. Brand feelings are customers' emotional responses and reactions to the brand. Keller (2003) identifies six types: warmth, fun, excitement, security, social approval and self-respect. Brand relationships constitute the final step in the pyramid where brand response is converted to create an intense, active loyalty relationship between customers and the brand. The pinnacle of the pyramid is resonance, which refers to the nature of the relationship between the customer and the brand. It is described as having four elements: 
behavioural loyalty, attitudinal attachment, sense of community and active engagement (Keller, 2001). There is an obvious sequence in this "branding ladder" and this meaning cannot be established unless identity has been created. Responses cannot occur unless the right meaning has been developed and the relationship cannot be forged unless the proper responses have been elicited (Keller, 2001).

\subsection{Yoo and Donthu (2002) brand equity model}

Yoo et al (2000) structural model of brand equity formation consists of three components: Marketing mix elements selected from the traditional " $4 \mathrm{p}$ " marketing activity (i.e. price store, image, distribution intensity, advertising spending, and price deals), brand equity dimensions (i.e. perceived product quality, brand loyalty, and brand awareness/associations) and overall brand equity. According to the model, marketing managerial efforts can be classified into two types: brand -building activity and brand-harming activity. These authors extend Aaker's (1991) model by placing brand equity as a separate construct between the dimensions of brand equity and the value for the customer and the firm. In addition, Yoo and Donthu (2001) developed and validated cross-culturally invariant multidimensional consumer-based brand equity. They tried to extend the brand equity concept; for instance brand loyalty in their research refers to the tendency to be loyal to a focal brand, which is demonstrated by the intention to buy the brand as a primary choice, in contrast other researches that relied on behavioral aspects of brand loyalty. They combined brand awareness and brand associations into one group and focused on three of assets; brand awareness/associations, perceived quality and brand loyalty. By mapping the assets of brand equity it is possible to determine if some aspects of brand equity seen to be more important than others for the consumer, or if a brand is lagging behind in one or many dimensions. In order for a brand to maintain high brand equity and be the preferred choice of consumers, it is important that it stays in tune with how the brand is perceived by firm's customer base.

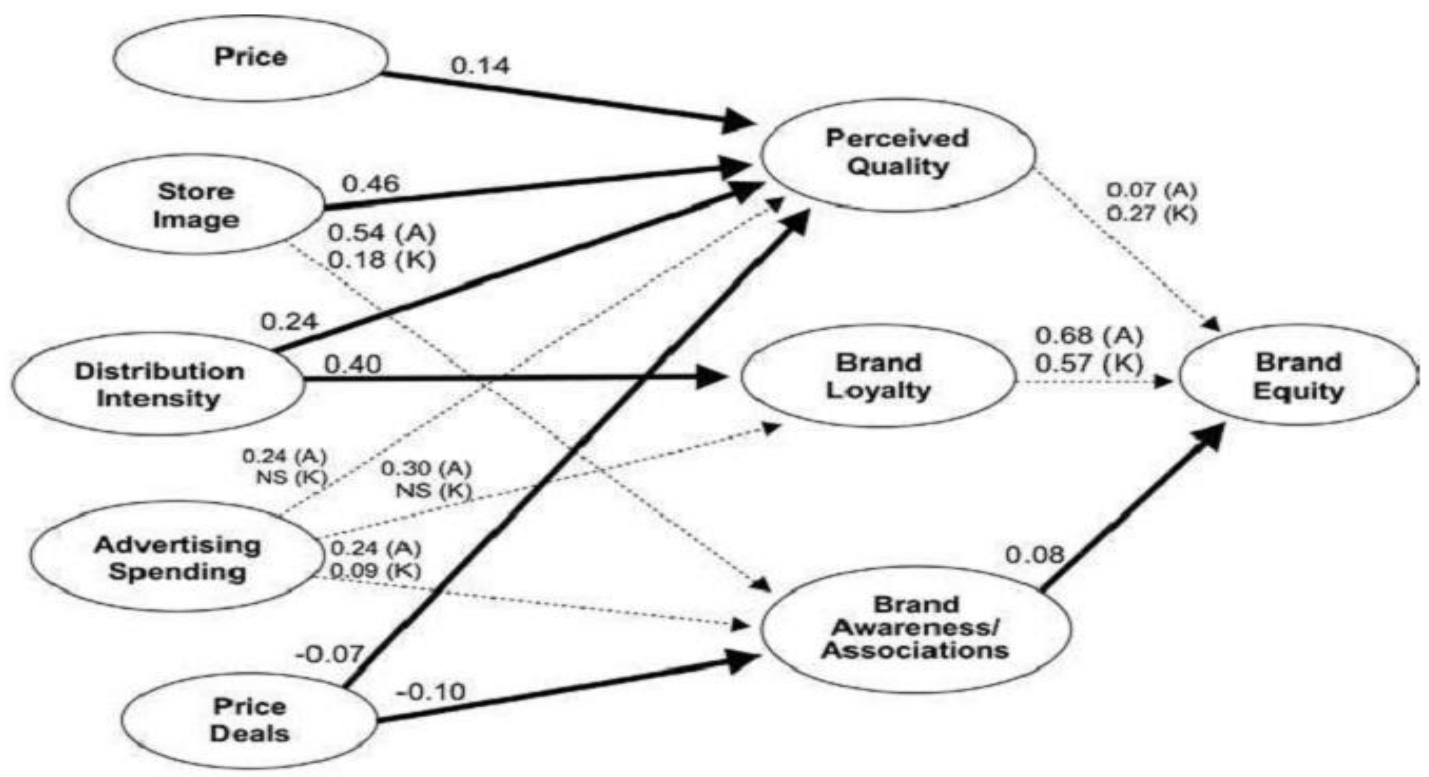

Figure 3. Structural brand equity model (source: Yoo et al (2002))

\subsection{Luming Wang and Adam Finn customer based brand equity model (2013)}

Model presented by Luming Wang and Adam Finn (2013) is quite different from prior consumer-based brand equity (CBBE) research that examined well-known brands in different product categories. Their research focused on the within-product category differences in terms of the sources of CBBE. To facilitate the comparison, they proposed a hybrid measurement model of CBBE that systematically integrates various existing CBBE dimensions and examined the substantive difference among master brands and their sub-brands within a product category. They explained that this model distinguishes the latent CBBE construct from its dimensions, and separates its formative dimensions (causes of CBBE) from its reflective (effects of CBBE) dimensions based on the causal relationship with the construct. They 
added another formative dimension, that is brand emotions, to expand the coverage of the CBBE domain from solely cognitive to include cognitive and non-cognitive, spontaneous emotional reactions to brands. They emphasized that formative dimension (such as uniqueness and perceived quality) jointly define CBBE. Eliminating any of them may alter the conceptual domain of the construct and decreases the construct validity; especially, formative dimensions can be used to identify potential; cannibalization effects among sister sub-brands within a brand portfolio.

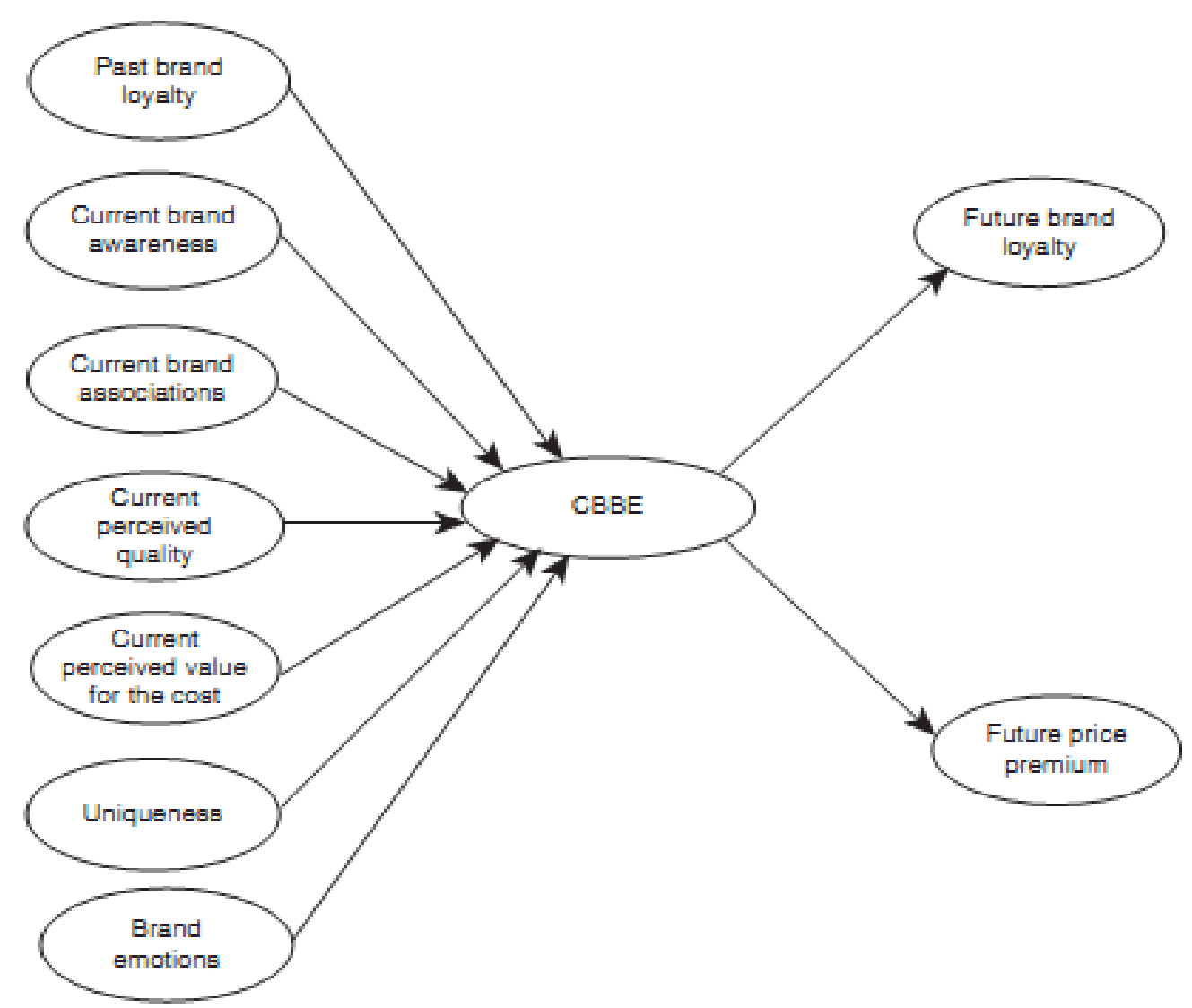

Figure 4. Customer-based brand equity Model (source: Luming Wang and Adam Finn (2013))

\subsection{Destination brand equity model}

Few researches related to evaluation of destination brands had been done. Model proposed by Boo et al (2009) is one of the most practical models among a review of the broad literature in this area. Measurement assumptions of the model include:

(1) A destination brand could be measured by employing the concept of customer-based brand equity;

(2) Destination brands should be evaluated by comparison with other competitive destination(s) in the same destination brand category;

(3) The destinations should be well-known and popular among tourists;

(4) Tourists must have experienced the destinations as tourists.

These assumptions distinguish the unique characteristics of destination brand measurement. Destination brand experience can be considered an emerging concept of the destination brand equity measurement model in terms of a destination context. They emphasized that this is unique and different from the construct that is suggested in retail brand equity measurement approaches. Destination brand experience had a positive effect on destination brand value. However, destination brand experience did not influence destination brand loyalty directly. Furthermore, Boo et al (2009) explained that destination brand awareness affected destination brand experience directly. Top-of-mind 
awareness can be an important predictor of tourists' destination brand experiences. Their research offers enhanced insight into how tourists perceive a destination brand, indicating that a specification of the destination brand measurement model, free from the established relationships in the marketing literature (i.e., relationships among awareness, image, quality, value, and loyalty), needs to be developed. The specified theoretical model was only one plausible model of the data, and the direction of the paths was theoretical. Basically, they focused specifically on the factors related to destination brand equity.

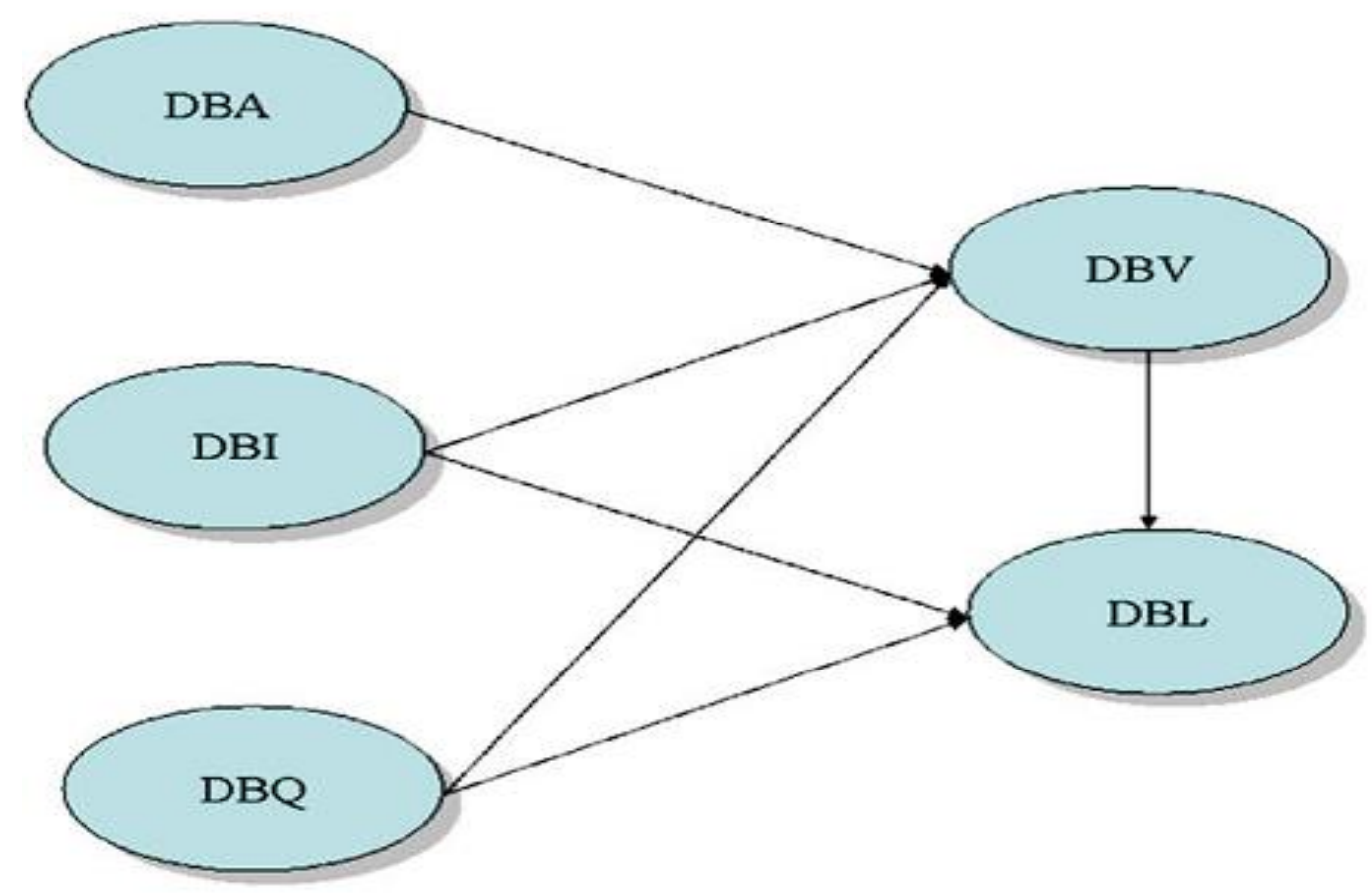

Fig. 1. The proposed baseline model. Note. DBA (destination brand awareness), DBI (destination brand image), DBQ (destination brand quality), DBV (destination brand value), DBL (destination brand loyalty).

Figure 5. Destination brand equity model (source: Boo et al (2009))

\subsection{CAA integrated brand equity model}

Wang.H et al (2008) indicated that there is a growing interest in brand formation and brand valuation among global firms, but global marketers typically ignore one of the key factors of brand building - corporation ability association (CAA). They represent the model which tries to explore the structural relationship between CAA and consumer-based brand equity variables and its product-market outcomes. They utilized Aaker and Keller's theoretical framework of brand equity and developed a brand equity model combining customer-based brand equity with product-market outcome approaches. Set of scales are developed and tested on a national sample of Chinese consumers. The final results in their research indicate that CAA is an important factor in building and preserving brand equity. CAA and brand awareness have impact on quality perception, which has positive impact on brand resonance, brand extensibility, and price flexibility. Brand resonance has positive influence on brand extensibility and the intention to repurchase. In addition, they argued that for global marketers operating in China, brand equity is a culturally market-based asset and global companies must focus on building corporation ability association in China in order to enjoy the substantial competitive and economic advantages provided by brand equity. 


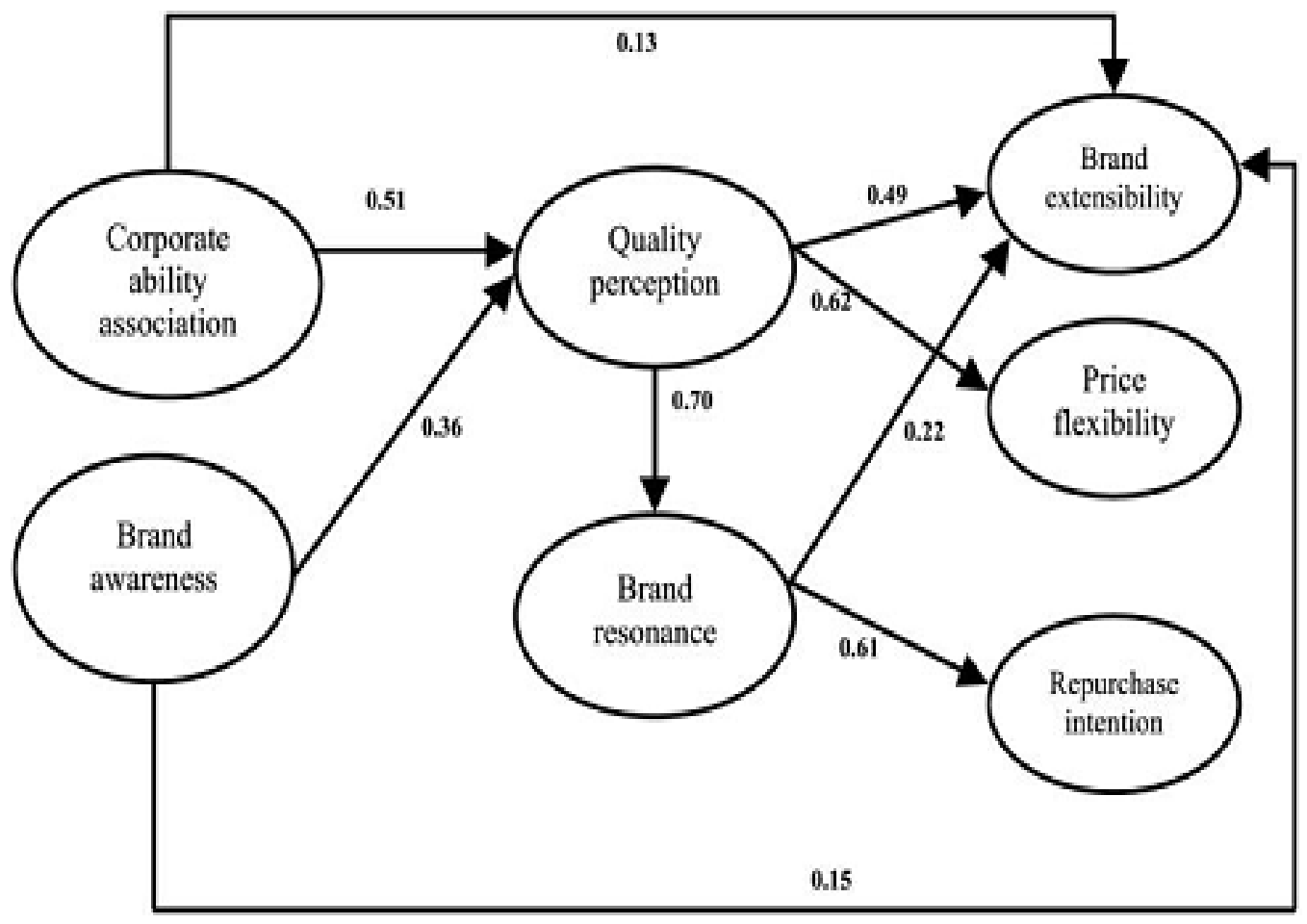

Figure 6. CAA integrated brand equity model (source: Wang.H et al (2008))

\section{Cross-national brand equity}

Another challenge related to CBBE content is about applying marketing theories in cross-national, multi-sector settings. Brand equity is conceptualised as a multi-dimensional concept and despite the considerable interest in the concept of brand equity and its measurement, there have been few attempts at its cross-national validation and only little research exists on the role of CBBE in international marketing using consumer data (Buil et al. 2008, Christodoulides et al.2015) and most of empirical researches on brand equity have focused largely on single country data, particularly from the USA (Christodoulides et al.2015). There is a summary of cross-national brand equity (see table 2)

Table 2. Studies of brand equity with international samples (source: Christodoulides at el. (2015), extended by Author)

\begin{tabular}{|c|c|c|c|c|}
\hline Paper & $\begin{array}{l}\text { Product } \\
\text { service } \\
\text { categories }\end{array}$ & $\begin{array}{l}\text { Conceptualizatio } \\
n \text { of brand equity }\end{array}$ & Sample & Sample size \\
\hline $\begin{array}{l}\text { Yoo and Donthu, } \\
\text { (2001) }\end{array}$ & $\begin{array}{l}\text { Preselected } \\
\text { brands of athletic } \\
\text { shoes, film and } \\
\text { colour TV sets }\end{array}$ & $\begin{array}{l}\text { Aaker's resulting } \\
\text { dimensions: Brand } \\
\text { Loyalty, Perceived } \\
\text { Quality, } \\
\text { Awareness/associa } \\
\text { tions }\end{array}$ & $\begin{array}{l}\text { Undergraduate } \\
\text { Students }\end{array}$ & $\begin{array}{l}\text { USA }-196 ; \\
\text { South Korea - } \\
218\end{array}$ \\
\hline Hsieh, (2004) & $\begin{array}{l}\text { Preselected } \\
\text { brands of } \\
\text { automobiles }\end{array}$ & $\begin{array}{l}\text { Data from a data } \\
\text { set owned by } \\
\text { MORPACE } \\
\text { International, a } \\
\text { multi-national } \\
\text { research firm with } \\
\text { measures for: } \\
\text { Brand recognition, } \\
\text { Brand attachment, } \\
\text { Market size }\end{array}$ & $\begin{array}{l}\text { General public } \\
\text { Living in various } \\
\text { cities of different } \\
\text { countries }\end{array}$ & $\begin{array}{l}\text { From } 44 \text { to } 189 \\
\text { in each country, } \\
\text { a total of } 2828 \\
\text { respondents }\end{array}$ \\
\hline
\end{tabular}




\begin{tabular}{|c|c|c|c|c|}
\hline Buil et al. (2008) & $\begin{array}{l}\text { Preselected } \\
\text { brands of soft } \\
\text { drinks, } \\
\text { sportswear, cars } \\
\text { and consumer } \\
\text { electronics }\end{array}$ & $\begin{array}{l}\text { Aaker's } \\
\text { Dimensions: } \\
\text { Brand awareness, } \\
\text { Perceived quality, } \\
\text { Brand loyalty, } \\
\text { Brand } \\
\text { associations: } \\
\text { perceived value, } \\
\text { brand personality, } \\
\text { Organization }\end{array}$ & $\begin{array}{l}\text { Birmingham } \\
\text { (UK), Zaragoza } \\
\text { (Spain), quota } \\
\text { sampling }\end{array}$ & $\begin{array}{l}\text { UK-411, Spain } \\
-411\end{array}$ \\
\hline $\begin{array}{l}\text { Jung and Sung, } \\
(\mathbf{2 0 0 8 )}\end{array}$ & $\begin{array}{l}\text { Three preselected } \\
\text { brands (Polo, } \\
\text { Gap and Levi's) }\end{array}$ & $\begin{array}{l}\text { Multi-dimensional } \\
\text { brand equity } \\
\text { (MBE) and overall } \\
\text { brand equity } \\
\text { (OBE) models } \\
\text { developed by Yoo } \\
\text { and Donthu } \\
\text { (2001) }\end{array}$ & College Students & $\begin{array}{l}\text { Americans in } \\
\text { the USA 100; } \\
\text { South Koreans } \\
\text { in USA 100; } \\
\text { South Koreans } \\
\text { in South Korea } \\
100\end{array}$ \\
\hline $\begin{array}{l}\text { Lehmann et al., } \\
\text { (2008), Study } 1\end{array}$ & $\begin{array}{l}\text { Preselected } \\
\text { brands of soft } \\
\text { drinks }\end{array}$ & $\begin{array}{l}27 \text { dimensions of } \\
\text { brand } \\
\text { performance were } \\
\text { suggested based } \\
\text { on extant } \\
\text { literature; Aaker } \\
\text { (1996), Fournier } \\
\text { (1998), Ambler } \\
\text { (2003),Keller } \\
\text { (2002, 2008) and } \\
\text { Keller and } \\
\text { Lehmann (2003) } \\
\text { and reports from } \\
\text { commercial brand } \\
\text { tracking } \\
\text { approaches, } \\
\text { including Young } \\
\text { and Rubicam's } \\
\text { Brand Asset } \\
\text { Valuator (BAV), } \\
\text { Millward Brown } \\
\text { and Research } \\
\text { International }\end{array}$ & $\begin{array}{l}\text { Chicago (USA), } \\
\text { Shanghai }\end{array}$ & $\begin{array}{l}\text { USA - 100, } \\
\text { China }-100\end{array}$ \\
\hline $\begin{array}{l}\text { Lehmann et al., } \\
\text { (2008) Study } 2\end{array}$ & $\begin{array}{l}\text { Preselected } \\
\text { brands of soft } \\
\text { drinks, toothpaste } \\
\text { and fast food }\end{array}$ & $\begin{array}{l}\text { The same } \\
\text { dimensions of } \\
\text { Study 1, measured } \\
\text { with } 3 \text { items per } \\
\text { dimension }\end{array}$ & $\begin{array}{l}\text { Chicago (USA), } \\
\text { Shanghai (China) }\end{array}$ & $\begin{array}{l}\text { USA - } 150, \\
\text { China }-150\end{array}$ \\
\hline $\begin{array}{l}\text { Broyles et al., } \\
(2010)\end{array}$ & $\begin{array}{l}\text { Preselected } \\
\text { brand: KFC }\end{array}$ & $\begin{array}{l}\text { Functional aspect } \\
\text { consisting of } \\
\text { perception of a } \\
\text { brand's } \\
\text { performance and } \\
\text { quality (perceived } \\
\text { performance and } \\
\text { perceived quality); } \\
\text { Experiential } \\
\text { component } \\
\text { consisting of } \\
\text { brand's resonance } \\
\text { and imagery }\end{array}$ & $\begin{array}{l}\text { University } \\
\text { Students }\end{array}$ & $\begin{array}{l}\text { USA - } 278, \\
\text { China }-300\end{array}$ \\
\hline
\end{tabular}




\begin{tabular}{|c|c|c|c|c|}
\hline $\begin{array}{l}\text { Hakala et al., } \\
(2012)\end{array}$ & $\begin{array}{l}\text { Beverages, } \\
\text { computers and } \\
\text { cell-phones }\end{array}$ & $\begin{array}{l}\text { Explored relations } \\
\text { between } \\
\text { consumers' } \\
\text { awareness of } \\
\text { brands, attitudes } \\
\text { related to brand } \\
\text { equity, and } \\
\text { changes in cultural } \\
\text { context. }\end{array}$ & $\begin{array}{l}\text { University } \\
\text { students }\end{array}$ & $\begin{array}{l}\text { USA - 198, } \\
\text { Finland -129, } \\
\text { France -231, } \\
\text { Sweden- } 185\end{array}$ \\
\hline $\begin{array}{l}\text { Yi-Cheon Yim et } \\
\text { al., (2014) }\end{array}$ & $\begin{array}{l}\text { Luxury brands } \\
\text { including } \\
\text { Armani, } \\
\text { Burberry, Chanel, } \\
\text { Gucci, Louis } \\
\text { Vuitton, Prada, } \\
\text { and Ralph Lauren }\end{array}$ & $\begin{array}{l}\text { cultural dimension } \\
\text { constructs } \\
\text { (horizontal } \\
\text { individualism, } \\
\text { vertical } \\
\text { individualism, } \\
\text { horizontal } \\
\text { collectivism, and } \\
\text { vertical } \\
\text { collectivism) that } \\
\text { are antecedent to } \\
\text { consumer SNII } \\
\text { and 2) the } \\
\text { endogenous part } \\
\text { of the model }\end{array}$ & College students & $\begin{array}{l}\text { UK 174, } \\
\text { Taiwan } 209\end{array}$ \\
\hline $\begin{array}{l}\text { Isabel Buil et al., } \\
(2013)\end{array}$ & $\begin{array}{l}\text { Three product } \\
\text { categories and six } \\
\text { brands: Adidas } \\
\text { and Nike for } \\
\text { sportswear; Sony } \\
\text { and Panasonic for } \\
\text { electronics; and } \\
\text { BMW } \\
\text { Volkswagen for } \\
\text { cars }\end{array}$ & $\begin{array}{l}\text { Builds on Keller's } \\
\text { (1993) and } \\
\text { Aaker's (1991) } \\
\text { definitions. Brand } \\
\text { awareness was } \\
\text { measured with } \\
\text { five items that } \\
\text { assess recall, } \\
\text { recognition and } \\
\text { familiarity of the } \\
\text { brand (Yoo et al., } \\
\text { 2000; Netemeyer } \\
\text { et al., 2004). }\end{array}$ & $\begin{array}{l}\text { General national } \\
\text { population }\end{array}$ & $\begin{array}{l}\text { UK -302, } \\
\text { Spain-305 }\end{array}$ \\
\hline
\end{tabular}

\section{Conclusion}

This paper has attempted to review and integrate studies on brand equity. With significant changes occurred with regard to concept of brand equity over the last two decade, it seems that it is necessary to have a better understanding of it in different sectors and different regions. We can discuss the brand equity from 3 different perspectives; financialbased, customer-based and employee-based perspectives. Brand equity plays an important role in lowering perceived risk for new product adoption, even in situations dominated by functional purchasing decisions.( Stavros et al 2012). Baldauf et al. (2003) indicate that brand equity contributes directly to the enhancement of value to customers. Brand equity provides information and serves as a source of confidence and satisfaction. Aaker (1992) was apparently the first to suggest the practical model for assessing brand equity, especially, from customer perspective. Many researchers consider that his model has undoubtedly a major impact on the business and academic communities. We discussed other effective scales. In addition, this paper tried to review different brand equity models, and presented a collection of models and definitions of brand equity. More than sixty papers related to brand equity from reliable sources are considered in this paper. Some suggestion for future research can be reviewing FBBE and EBBE perspectives. Moreover, we considered several important brand equity models and we can classify these models to different sections such as product, service categories or based on one special field. 
Table 3. Mostly cited "Brand Equity" studies (source: Taleghani et al (2011))

\begin{tabular}{|c|c|c|}
\hline Author & Dimensions of Brand Equity & Related Findings \\
\hline Aaker (1996) & $\begin{array}{l}\text { Brand loyalty, perceived quality, brand } \\
\text { awareness, brand associations }\end{array}$ & $\begin{array}{l}\text { Four dimensions of brand equity } \\
\text { represent customer perceptions of } \\
\text { the brand and could be applied } \\
\text { Across markets and products. }\end{array}$ \\
\hline Keller (1993) & Brand awareness, brand image & $\begin{array}{l}\text { When the consumer is familiar with } \\
\text { the brand and holds some } \\
\text { favourable, strong, and unique brand } \\
\text { associations in the memory, then } \\
\text { customer-based brand equity occurs }\end{array}$ \\
\hline $\begin{array}{l}\text { Park and } \\
\text { Srinivasan } \\
(1994)\end{array}$ & $\begin{array}{l}\text { Brand associations (Attribute-based and } \\
\text { non-attribute-based component of brand } \\
\text { equity) }\end{array}$ & $\begin{array}{l}\text { The non-attribute-based component } \\
\text { of brand equity appears to play a } \\
\text { more dominant role in determining a } \\
\text { brand's equity }\end{array}$ \\
\hline $\begin{array}{l}\text { Lane and } \\
\text { Jacobson } \\
(1995)\end{array}$ & $\begin{array}{l}\text { Brand attitude, brand name familiarity The } \\
\text { stock market participants' responses to } \\
\text { brand extension }\end{array}$ & $\begin{array}{l}\text { announcements depend on brand } \\
\text { attitude and familiarity }\end{array}$ \\
\hline $\begin{array}{l}\text { Cobbwalgren, } \\
\text { Ruble, and } \\
\text { Donthu } \\
\text { (1995) }\end{array}$ & $\begin{array}{l}\text { Perceived quality, brand awareness, brand } \\
\text { associations, advertising awareness }\end{array}$ & $\begin{array}{l}\text { The brand with greater advertising } \\
\text { budget yielded substantially higher } \\
\text { levels of brand equity. In turn, the } \\
\text { brand with the higher equity } \\
\text { generated significantly greater } \\
\text { preference and purchase intentions. }\end{array}$ \\
\hline Aaker (1996) & $\begin{array}{l}\text { Brand loyalty, perceived quality, brand } \\
\text { awareness, brand associations }\end{array}$ & $\begin{array}{l}\text { Four dimensions of brand equity } \\
\text { represent customer perceptions of } \\
\text { the brand and could be applied } \\
\text { Across markets and products. }\end{array}$ \\
\hline $\begin{array}{l}\text { Yoo, Donthu, } \\
\text { and Lee } \\
(2000)\end{array}$ & $\begin{array}{l}\text { Brand loyalty, perceived quality, brand } \\
\text { awareness/associations }\end{array}$ & $\begin{array}{l}\text { Brand equity is positively related to } \\
\text { perceived quality, brand loyalty, and } \\
\text { brand associations. The relationship } \\
\text { of perceived quality and brand } \\
\text { associations to brand equity is much } \\
\text { weaker than the relationship of } \\
\text { brand loyalty to brand equity }\end{array}$ \\
\hline Berry (2000) & $\begin{array}{l}\text { Brand awareness, brand meaning } \\
\text { (customer's dominant perceptions) }\end{array}$ & $\begin{array}{l}\text { Positive service brand equity } \\
\text { emerges from the synergy of brand } \\
\text { awareness and brand meaning. }\end{array}$ \\
\hline $\begin{array}{l}\text { Yoo and } \\
\text { Donthu } \\
(\mathbf{2 0 0 1 )}\end{array}$ & $\begin{array}{l}\text { Brand loyalty, perceived quality, brand } \\
\text { awareness/associations }\end{array}$ & $\begin{array}{l}\text { A multidimensional brand equity } \\
\text { scale is validated across Americans, } \\
\text { Korean Americans and Koreans } \\
\text { samples }\end{array}$ \\
\hline Gil (2007) & $\begin{array}{l}\text { Brand loyalty, perceived quality, brand } \\
\text { Awareness, brand associations }\end{array}$ & $\begin{array}{l}\text { Brand loyalty is much closer to the } \\
\text { concept of overall brand equity than } \\
\text { brand Awareness-associations and } \\
\text { perceived quality. }\end{array}$ \\
\hline Atilgan (2009) & $\begin{array}{l}\text { Brand loyalty, perceived quality, brand } \\
\text { Awareness, Brand associations, Brand } \\
\text { Trust }\end{array}$ & $\begin{array}{l}\text { Emergence of brand trust as a new } \\
\text { dimension instead of brand } \\
\text { awareness complies well with recent } \\
\text { literature on global branding, }\end{array}$ \\
\hline $\begin{array}{l}\text { Mishra and } \\
\text { Datta (2011) }\end{array}$ & $\begin{array}{l}\text { Brand Name, Brand Communication, } \\
\text { Brand Association, Brand Personality, } \\
\text { Brand Awareness, Brand Image, Perceived } \\
\text { Brand quality, Brand Loyalty }\end{array}$ & $\begin{array}{l}\text { Importance of the effect of the brand } \\
\text { assets treated as antecedents like } \\
\text { brand name, awareness, personality } \\
\text { and consequences like brand } \\
\text { preference and purchase intention on } \\
\text { customer based brand equity. }\end{array}$ \\
\hline
\end{tabular}




\section{References}

- Aaker, D. (1989): Managing Assets and Skills: The Key to Sustainable Competitive Advantage. California Management Review, 21 (3), 91-106.

- Aaker, D. and Stayman. D. (1990): Measuring Audience Perceptions of Commercials and relating them to Ad Impact. Journal of Advertising Research. 30 (4), 7-17.

- Aaker, D. A. (1991): Managing Brand Equity: Capitalizing on the Value of a Brand Name. Free Press, New York.

- Aaker, D. A. (1992),’The Value of Brand Equity”, Journal of Business Strategy, Vol. 13 Issue 4 pp. 27 - 32

- Ailawadi, Kusum L., Donald R. Lehmann, and Scott A. Neslin (2003), "Revenue Premium as an Outcome Measure of Brand Equity, "Journal of Marketing, 67(4), 1-17.

- Ashforth, B. E., and Mael, F. (1989). Social identity theory and the organization. Academy of Management Review, 14, 20-39

- Atilgan, E., Aksoy, S., and Akinci, S. (2005). Determinants of the brand equity: A verification approach in the beverage industry in Turkey. Marketing Intelligence and Planning, 23), 237 - 248.

- Baalbaki, Sally Samih, (2012) Consumer Perception of Brand Equity Measurement: A New Scale,

- $\quad$ page 16,Dissertation of doctor of philosophy, Univeristy of North Texas

- Baldauf, A., Cravens, K.S. and Binder, G. (2003), "Performance consequences of brand equity management evidence from organizations in the value chain", Journal of Product and Brand Management, Vol. 12 No. 4, pp. 220-236

- Berry, L.L. (2000), “Cultivating service brand equity”, Journal of the Academy ofMarketing Science, Vol. 28 No. 1, pp. 128-38

- Broyles, A., Leingpibul, T., Ross R. and Foster, B. (2010), "Brand equity's antecedent/consequence relationships in cross-cultural settings", Journal of Product and Brand Management, Vol. 19 No. 3, pp. 159169.

- Buil, I., de Chernatony, L. and Martinez E. (2008), “A cross-national validation of the consumer-based brand equity scale “, Journal of Product and Brand Management, Vol. 17 No. 6,pp. 384-392

- Chen, L.-H. (2008), "Internationalization or international marketing? Two frameworks for understanding international students' choice of Canadian universities", Journal of Marketing for Higher Education, Vol. 18 No. 1, pp. 1-33.

- Christodoulides G, John W. Cadogan Cleopatra Veloutsou, (2015), "Consumer-based brand equity measurement: lessons learned from an international study", International Marketing Review, Vol. 32 Issue 3/4 pp. $307-328$

- Clow, Kenneth E. and Donald Baack (2005), "Brand and Brand Equity”, Concise Encyclopedia of Advertising, Haworth Press, Inc.

- Cobb-Walgren, C. J., Ruble, C. A., and Donthu, N. (1995). Brand equity, brand preference, and purchase intent. Journal of Advertising, 24(3), 25-40.

- De Chernatony, L., Cottam, S. 2006. Internal brand factors driving successful financial services brands. European Journal of Marketing 40 (5/6), 611 - 633.

- $\quad$ Falkenberg, A.W. (1996) "Marketing and the Wealth of Firms" Journal of Macromarketing, 16, 4, pp.4-24.

- Farquhar, P.H. (1989), “Managing brand equity”, Marketing Research, Vol. 1, September, pp. 24-33

- Isabel Buil Eva Martínez Leslie de Chernatony, (2013),"The influence of brand equity on consumer responses", Journal of Consumer Marketing, Vol. 30 Issue 1 pp. 62 - 74

- Gil, R.B., E.F. Andres and E.M. Salinas, 2007. Family as a source of consumerbased brand equity. J. Prod. Brand Manage. 16(3): 188-99.

- Hsieh, M.H. (2004), “ Measuring global brand equity using cross-national survey data “, Journal of International Marketing, Vol. 12 No. 2, pp. 28-57

- Haizhong Wang Yujie Wei Chunling Yu, (2008),"Global brand equity model: combining customer-based with product-market outcome approaches", Journal of Product and Brand Management, Vol. 17 Issue 5 pp. 305 316

- Isabel Buil Eva Martínez Leslie de Chernatony, (2013),"The influence of brand equity on consumer responses", Journal of Consumer Marketing, Vol. 30 Issue 1 pp. 62 - 74

- Jung, J. and Sung, E.Y. (2008), "Consumer based brand equity: comparisons among and South Koreans in the USA and South Koreans in Korea”, Journal of Fashion Marketing and Management, Vol. 12 No. 1, pp. 24-35.

- Keller, K. L. (1993): Conceptualizing, Measuring, and Managing Customer-Based Brand Equity. Journal of Marketing, 57 (1), 1-22.

- Keller, K.L. (2003). Strategic Brand Management: Building, Measuring and Managing Brand Equity, 2nd ed., Prentice-Hall, Englewood Cliffs, NJ.

- Keller, Kevin L. and Donald R. Lehmann (2003), "How Do Brand Create Value,” Marketing Management, 
2003 (May), (26-31).

- Kerri-Ann L. Kuhn Frank Alpert Nigel K. Ll. Pope, (2008),"An application of Keller's brand equity model in aB2B context", Qualitative Market Research: An International Journal, Vol. 11 Issue 1 pp. 40 - 58

- Kim, Hong-Bumm, Woo Gon Kim, and Jeong A. an (2003), "The Effect of Consumer-Based Brand Equity on Firms' Financial Performance", Journal of Consumer Marketing, 20 (4), 335-351.

- King, C. and Grace, D. (2009). Employee based brand equity: A third perspective. Services Marketing Quarterly, 30(2), 122-147.

- King, Ceridwyn, Debra Grace., 2005. Exploring the role of employees in the delivery of the brand: a case study approach. Qualitative Market Research: An International Journal 8 (3), 277-95.

- Krishnan, B. C., and Hartline, M. D. 2001. „Brand equity: is it more important in services? “, Journal of Services Marketing, vol. 15, no. 5, pp. 328-342.

- Kotler, P. and Keller, K.L. (2006), Marketing Management, Pearson Education, Upper Saddle River, NJ

- Lassar, Walfried, Banwari Mittal, and Sharma Arun (1995), "Measuring Customer-Based Brand Equity", Journal of Consumer Marketing, 12 (4), 11-19.

- Lee, M.Y. and Oh K.Y. (2006), "An exploratory study on brand personality: the case of a traditional casual brand in Korea", Journal of Fashion Business, Vol. 10 No. 6, pp. 79-90.

- Lehmann, D.R., Keller, K.L. and Farley, J.U. (2008), "The structure of survey-based brand metrics “, International Marketing Review, Vol. 16 No. 4, pp. 29-56.

- Lisa Wood, (2000) "Brands and brand equity: definition and management", Management Decision, Vol. 38 Issue: 9 , pp.662 - 669

- Luming Wang Adam Finn , (2013),"Heterogeneous sources of customer-based brand equity within a product category", Marketing Intelligence and Planning, Vol. 31 Issue 6 pp. $674-696$

- Manoj K. Agarwal, Vithala R. Rao( 1996) Marketing Letters an Empirical Comparison of Consumer-Based Measures of Brand Equity, Marketing Letters 7:3 , 237-247

- Mark Yi-Cheon Yim Paul L. Sauer Jerome Williams Se-Jin Lee Iain Macrury, (2014),"Drivers of attitudes toward luxury brands", International Marketing Review, Vol. 31 Issue 4 pp. $363-389$

- Martensen, A. and Gronholdt, L. (2004): Building Brand Equity: A Customer-Based Modelling Approach. Journal of Management Systems, 16 (3), 37-51

- Mishra. Pallabi, Datta. Biplab,(2011),Perpetual Asset Management of Customer-Based Brand Equity-The PAM Evaluator, India, Journal of Social Sciences 3(1):34-43

- Mohammad Taleghani, Meysam Almasi (2011), "Evaluate the Factors Affecting Brand Equity from the Perspective of Customers Using Aaker's Model", Kuwait Chapter of Arabian Journal of Business and Management Review Vol. 1, No.4; December 2011

- Myers, R. (2003). Using marketing research effectively. Business NH Magazine, 20(9), 25.

- Ovidiu Ioan Moisescu,(2005), The concept of brand equity - A comparative approach-MPRA Paper No. 32013

- Park CS, Srinivasan V. A survey-based method for measuring and understanding brand equity and its extendibility. J Mark Res 1994;31(May):271 \pm 88

- Pitta, D.A. and Katsanis, L.P. (1995), "Understanding brand equity for successful brand extension”, Journal of Consumer Marketing, Vol. 12 No. 4, pp. 51-64

- R.L. Cardy et al.(2007), Employee equity: Toward a person-based approach to HRM / Human Resource Management Review 17 (2007) 140-151

- Rangaswamy A, Burke R, Oliva TA. Brand equity and the extendibility of brand names. Int J Res Mark 1993; 10 (March): $61 \pm 75$

- Ravi Pappu Pascale G. Quester Ray W. Cooksey, (2005),"Consumer-based brand equity: improving the measurement -empirical evidence", Journal of Product and Brand Management, Vol. 14 Issue 3 pp. 143 - 154

- Reza Motameni Manuchehr Shahrokhi, (1998),"Brand equity valuation: a global perspective", Journal of Product and Brand Management, Vol. 7 Issue 4 pp. 275 - 290

- Simon, C. J., and Sullivan, M. W. (1993). "The measurement and determinants of brand equity: a financial approach". Marketing science, 12(1), 28-52.

- Stavros P. Kalafatis Natalia Remizova Debra Riley Jaywant Singh, (2012),”The differential impact of brand equity on B2B cobranding", Journal of Business and Industrial Marketing, Vol. 27 Issueue 8 pp. 623 - 634

- Szöcs(2012), Ph. D. dIssueertation,, The MIMIC model of the consumer-based brand equity, Testing the causal specification of consumer-based brand equity,

- Ulla Hakala Johan Svensson Zsuzsanna Vincze, (2012),"Consumer-based brand equity and top-of-mind awareness: a cross-country analysis", Journal of Product and Brand Management, Vol. 21 Issue 6 pp. 439 451

- Vazquez, R., Del Rio, Belen A., and Iglesias, V. (2002). Consumer-based brand equity: development and validation of a measurement instrument. Journal of Marketing Management 18, 27-48.

- Norjaya Mohd Yasin Mohd Nasser Noor Osman Mohamad, (2007),’'Does image of country-of-origin matter 
to brand equity?",

- Journal of Product and Brand Management, Vol. 16 Issue 1 pp. 38 - 48

- Yoo, B. and Donthu, N. (1997): Developing and Validating a Consumer-Based Overall Brand Equity Scale for Americans and Koreans: An Extension of Aaker's and Keller's Conceptualizations. Paper Presented at AMA Summer Educators Conference, Chicago.

- Yoo, B. and Donthu, N. (2001): Developing and Validating a Multidimensional Consumer-Based Brand Equity Scale. Journal of Business Research, 52 (1), 1-14.

- Yoo, B., Donthu, N. and Lee, S. (2000): An Examination of Selected Marketing Mix Elements and Brand Equity. Journal of the Academy of Marketing Science, 28 (2), 195-211.

- Youngbum Kwon, (2013). The Influence of Employee-Based Brand Equity on the Health Supportive Environment and Culture - Organizational Citizenship Behaviour Relation A dIssueertation of Doctor of Philosophy, University of Michigan

- Zeithaml, V. A. (1988). Consumer perception of price, quality, and value: a means-end

- Model and synthesis of evidence. Journal of Marketing, 52 (3), 2-22. 